\title{
Antioxidant activity, total phenolic and flavonoid contents of selected medicinal plants used for liver diseases and its classification with chemometrics
}

\author{
Harto Widodo ${ }^{1,2}$, Sismindari Sismindari ${ }^{3}$, Widya Asmara ${ }^{4}$, Abdul Rohman ${ }^{3,5^{*}}$ \\ ${ }^{1}$ Centre Study of Biotechnology, Gadjah Mada University, Yogyakarta, Indonesia. \\ ${ }^{2}$ Medicinal Plant and Traditional Medicine Research and Development Centre (MPTMRDC)—NiHRD RI, Indonesia. \\ ${ }^{3}$ Faculty of Pharmacy, Gadjah Mada University, Yogyakarta, Indonesia. \\ ${ }^{4}$ Department of Microbiology, Faculty of Veterinary Medicine, Gadjah Mada University, Yogyakarta, Indonesia. \\ ${ }^{5}$ Institute of Halal Industry and Systems, Gadjah Mada University, Yogyakarta, Indonesia.
}

\begin{tabular}{l}
\hline ARTICLE INFO \\
\hline Received on: 01/03/2019 \\
Accepted on: 06/04/2019 \\
Available online: 05/06/2019 \\
\hline Key words: \\
Antioxidant activity, \\
flavonoid, phenolic, \\
medicinal plant, traditional \\
healer, principal component \\
analysis.
\end{tabular}

\begin{abstract}
Liver disease has become one of the major health problems in the world, and the death rate is going rapidly to increase. Oxidative stress plays a crucial role in the emerging, development, and the progression of liver diseases. Ethnobotanical research has an undoubted profound impact on the development of numerous new drugs. The aim of this research, therefore, was to examine the antioxidant activities of 14 selected plants used for treating liver diseases by traditional healers of Indonesia ethnicities and to classify these plants using chemometrics of principal component analysis (PCA). The extraction using methanol as the solvent was performed with two stages maceration. Total phenolic and flavonoid compounds were determined by Folin-Ciocalteau and $\mathrm{AlCl}_{3}$ method, respectively, whereas antioxidant activity was estimated using 2,2'-diphenyl-2-picrylhydrazyl (DPPH) free radical scavenging, trolox equivalent antioxidant capacity (TEAC), and ferric reducing antioxidant power (FRAP) assay. Among 19 methanol extracts of 14 plants, the leaves of Baccaurea racemosa, Macaranga subpeltata, and Piper sp. showed the highest antioxidant properties. The phenolic content correlated with TEAC, FRAP, and DPPH radical scavenging activity, while flavonoid did not significantly affect these antioxidant activity methods. PCA successfully classified the plant samples using the variables of antioxidant activities and phenolic-flavonoid contents. The selected plants have promising antioxidant properties which support their utilization for either liver diseases medication or oxidative stress-related diseases prevention.
\end{abstract}

\section{INTRODUCTION}

Liver diseases become one of the major world health problems, and the death rate caused by this disease is rising rapidly in the US over the last decade (Reinberg, 2018). There are various liver diseases, including metabolic disorder (Wilson's disease and hemochromatosis), infection (virus, bacteria, fungi, and amoeba), liver cirrhosis, liver cancer, autoimmune, and xenobiotic substances (Anand and Lal, 2016). A comprehensive data about the amount of

"Corresponding Author

Abdul Rohman, Faculty of Pharmacy, Gadjah Mada University,

Yogyakarta, Indonesia.E-mail: abdul_kimfar@ugm.ac.id each kind of liver diseases in Indonesia is still limited except for hepatitis which its prevalence increases two times during 5 years (0.2\% in 2013 and $0.4 \%$ in 2018) (NiHRD RI, 2019).

Regardless of the liver diseases causal, inflammation is considered as the main causes of progression of the disease chronicity (Marcellin and Kutala, 2018). Oxidants affect all stages of the inflammatory; moreover, the undoubted evidences emphasize that oxidative stress plays a crucial role in the development of inflammation (Lugrin et al., 2014). Stress oxidative induced by various factors contributes to the initiation and progression of liver diseases. A condition in which this disturbance continues to occur resulting in severe liver diseases. Extra-hepatic organs damages, such as brain impairment and kidney failure, are among other 
consequences of systemic oxidative stress arising during liver diseases (Li et al., 2015).

The external exposures (environmental pollutants/toxicant and irradiation), the aging process, pathological incidents, and other factors are unavoidable events, leading to oxidative stress (Pandey and Rizvi, 2012). Therefore, maintaining a balanced state of oxidant and antioxidant to prevent oxidative stress is a crucial part of reasonable health maintenance (Sochor et al., 2010). Plants produce various phytochemicals which have a significant source of exogenous antioxidant as dietary intake (Chen et al., 2016), flavonoids, and phenolic compound are a reputable plant-derived antioxidant (Khoddami et al., 2013). Ethnobotanical/ethnopharmacological research has valuable roles in the pharmacological studies (McClatchey et al., 2009), even in discovering novel drugs (de Albuquerque, 2010; Ntie-Kang et al., 2013).

National Institute Health Research and Development Republic of Indonesia (NiHRD RI) has compiled enormous valuable metadata via "The Community Based Exploration of Local Knowledge of Ethno-medicine and Medicinal Plant in Indonesia" known as RISTOJA held in 2012, 2015, and 2017 (Widodo et al., 2019). According to that research, there were about 381 taxonomically identified species of plants had been used for liver disease medication by Indonesian ethnic traditional healer (IETH). Among these, three most frequently used plants for medication, this disease, were Bambusa vulgaris Schrad, Curcuma longa L., and Curcuma zanthorrhiza Roxb which taken apart as the main ingredient of 52,42, and 41 potions by 42, 34, and 33 IETHs throughout Indonesia, respectively. Those plants are well-studied and known their reputable antioxidant properties. This present study, therefore, was intended to evaluate antioxidant activities of some selected medicinal plants used for liver diseases medication by IETHs from the metadata and its correlation with phenolics and flavonoid contents.

\section{MATERIAL AND METHODS}

\section{Materials}

Plant samples were collected from the Province of Aceh [Piper sp., Poikilospermum erectum (Blanco) Merr.], Central Java [Baccaurea racemosa (Reinw. Ex Blume) Müll.Arg., Chromolaena odorata (L.) R.M.King \& H.Rob.., Litsea glutinosa (Lour.) C.B.Rob., Nenga pumila (Blume) H.Wendl., Paspalum conjugatum P.J.Bergius., Scaevola taccada (Gaertn.), Ipomoea pes-caprae (L.) R. Br.], Yogyakarta [Intsia bijuga (Colebr.) Kuntze, Peronema canescens Jack], and East Java (Stellaria vestita Kurz, Macaranga subpeltata K.Schum. \& Lauterb, Capparis sepiaria L.). These plants were authenticated in MPTMRDC-NiHRD RI. Methanol, Folin-Ciocalteau's phenol reagent (FCR), Acetic acid, $\mathrm{AlCl}_{3}, \mathrm{NaCO}_{3}, \mathrm{FeCl}_{3} \cdot 6 \mathrm{H}_{2} \mathrm{O}, \mathrm{FeSO}_{4} \cdot 7 \mathrm{H}_{2} \mathrm{O}, \mathrm{L}-(+)$-ascorbic acid were obtained from E. Merck (Darmstadt, Germany). 2,2'-diphenyl-2picrylhydrazyl (DPPH), 2,2'-azino-bis(3-ethylbenzothiazoline-6sulfonic acid) (ABTS), 2,4,6-Tris(2-pyridyl)-s-triazine (TPTZ), Trolox, Gallic acid, Quercetin, and Rutin were purchased from Sigma (Aldrich, USA). All materials used were analytical grade.

\section{Preparation of methanolic extract}

Preparation of methanolic extract was performed according to Mistriyani et al. (2018). Sample plants were washed, drained, oven-dried $\left(40^{\circ} \mathrm{C}\right)$, grounded, and sieved (60 mesh). Finely powdered plant materials were macerated using methanol $(1: 10 \mathrm{w} / \mathrm{v})$ as extracting solvent. The samples were mixed with $60 \%$ volume of solvent for 3 days (stirred every 6 hours), the solids were filtered and re-macerated using $40 \%$ volume of solvent for 3 days. Extracts were concentrated using vacuum rotary evaporator (Buchi) and then oven-dried $\left(40^{\circ} \mathrm{C}\right)$. The methanolic extracts were then subjected to evaluation of antioxidant activities, determination of phenolics content and flavonoid contents.

\section{Quantification of total phenolic contents}

Total phenolic contents (TPC) of methanol extracts of plant samples was measured using calibrated UV-Vis spectrophotometer (Multiskan Sky-Thermo Scientific, USA) as described by Cicco et al. (2009) with slight modifications. The final condition of the test solution: $40 \mathrm{mg}$ extract, $4 \%$ methanol, $10 \% \mathrm{FCR}$, and $5 \% \mathrm{CaCO}_{3}$. A $40 \mu \mathrm{l}$ of plant extract $(1 \mathrm{mg} / \mathrm{ml} ; 1$ $\mathrm{mg}$ dissolved in $1 \mathrm{ml}$ methanol) was mixed with $360 \mu \mathrm{l}$ of distilled water and $100 \mu \mathrm{l}$ of FCR, and the solution was shaken and left for 2 minutes. The reaction was neutralized using $500 \mu \mathrm{l}$ of $10 \%$ $\mathrm{CaCO}_{3}$ and mixed until homogeneous. The mixture was incubated for 20 minutes at $40^{\circ} \mathrm{C}$. A $150-\mu 1$ test solution was included in the microplate, and the absorbance was measured at wavelength $732 \mathrm{~nm}$. The TPC is expressed as $\mathrm{mg}$ gallic acid equivalent/g of the extract through linear regression prepared from gallic acid standards at various concentrations $(0,5,10,15,20$, and $25 \mu \mathrm{g} / \mathrm{ml})$.

\section{Quantification of total flavonoid contents}

Total flavonoid content (TFC) was measured spectrophotometrically according to $\mathrm{Li}$ et al. (2013) with slight modification. The reaction mixture consisted of $100 \mu \mathrm{l}$ extract $[1,250$ $\mu \mathrm{g} / \mathrm{ml}(\mathrm{w} / \mathrm{v})$ ], $150 \mu \mathrm{l}$ solution of $0.1-\mathrm{M} \mathrm{AlCl}_{3}$ (blank without $\mathrm{AlCl}_{3}$ and replaced with methanol $150 \mu \mathrm{l}), 350-\mu \mathrm{l}$ ultra-pure $\mathrm{dH}_{2} \mathrm{O}, 250$ $\mu \mathrm{l}$ acetate buffer ( $\mathrm{pH} 3.8$ ), and added with methanol up to a total volume of $1,250 \mu \mathrm{l}$. The test solution was incubated at $35^{\circ} \mathrm{C}$ for 30 minutes. TFC is expressed as rutin equivalents per $\mathrm{g}$ extract (mg $\mathrm{RE} / \mathrm{g}$ ) via generating a standard curve with a series concentrations of $0-100 \mu \mathrm{g} / \mathrm{ml}$ of rutin ( $x$-axis) against absorbance (y-axis). A $150 \mu \mathrm{l}$ of solution was pipetted into the microplate, and the absorbance was measured with a UV-Vis spectrophotometer at wavelength $398 \mathrm{~nm}$.

\section{DPPH radical scavenging activity}

2,2'-diphenyl-2-picrylhydrazyl (DPPH) radical scavenging activity of the sample extracts was determined according to Sharma and Bhat (2009) with a slight modification. The reaction was prepared to $1.0 \mathrm{ml}$ total volume with final concentrations of methanol extract $(0-100 \mu \mathrm{g} / \mathrm{ml})$ and DPPH (70 $\mu \mathrm{M})$. Absorbance at $515 \mathrm{~nm}$ was measured after 25-60 minutes (based on prior determined operating time). The percentage inhibition activity was calculated using $\left[\left(A_{0}-A_{1}\right) / A_{0}\right] \times 100$, where $A_{0}$ : the absorbance of the control and $A_{1}$ : the absorbance of the extract or standard. The inhibition curves were generated and $\mathrm{IC}_{50}$ values were calculated. L-(+)-ascorbic acid (Vitamin C) with final concentration $0-5 \mu \mathrm{g} / \mathrm{ml}$ was used as the standard antioxidant.

\section{Trolox equivalent antioxidant capacity assay}

The assay was performed according to Dong et al. (2015) as follows: a fresh ATBS++ working solution was made 
by dissolving $38.4 \mathrm{mg}$ of ABTS in $10 \mathrm{ml} 2.5 \mathrm{mM} \mathrm{K} \mathrm{S}_{2} \mathrm{O}_{8}$, mixed completely and kept in the dark (room temperature; $12-16$ hours). The solution was then diluted with methanol to obtain $0.70 \pm 0.02$ absorbance. A standard curve was generated by making a series with concentrations of $0-45 \mathrm{mM}$ of Trolox. Ten $\mathrm{mg}$ plant extracts were dissolved in $1 \mathrm{ml}$ methanol, sonicated (15 minutes), and diluted to get $100 \mu \mathrm{g} / \mathrm{ml}$.

\section{Ferric reducing antioxidant power assay}

The reducing ability of the plant extracts was estimated using the ferric reducing antioxidant power (FRAP) assay according to Benzie and Strain (1996) with minor modifications. The FRAP reagent was produced by mixing acetate buffer (300 $\mathrm{mM}$; $\mathrm{pH} 3.6), 10 \mathrm{mM}$ TPTZ solution in $40-\mathrm{mM} \mathrm{HCl}$, and 20$\mathrm{mM} \mathrm{FeCl} \cdot 6 \mathrm{H}_{2} \mathrm{O}$ solution in a volume ratio of $10: 1: 1$ prepared by daily basis preparation. $\mathrm{FeSO}_{4} \cdot 7 \mathrm{H}_{2} \mathrm{O}$ was used to generate a standard curve using final concentration $100-1,000 \mu \mathrm{M} / \mathrm{ml}$. The reaction mixture in a microtube $2 \mathrm{ml}$ contained $1,350 \mu \mathrm{l}$ of FRAP reagent and $150 \mu \mathrm{l}$ methanolic extract sample or standard antioxidants [Quercetin, L-(+)-ascorbic acid] solution. The tube was then incubated for 30 minutes at $37^{\circ} \mathrm{C}$, and the absorbance was recorded at $595 \mathrm{~nm}$. The FRAP value was calculated as M $\mathrm{Fe}^{2+} / \mathrm{g}$ of sample using ferric chloride standard curve.

\section{Data analysis}

Antioxidant assays using 2,2'-diphenyl-1-picrylhydrazyl (DDPH) scavenging activity, trolox equivalent antioxidant capacity (TEAC), and FRAP, as well as the determination of phenolics and flavonoid contents were performed in triplicates. All data were expressed as mean \pm standard deviation and processed using Excel (Microsoft Inc., USA). The chemometrics of principal component analysis (PCA) was performed using Minitab version 17 (Minitab Inc., USA).

\section{RESULTS AND DISCUSSION}

Oxidative stress is considered as a causative factor of the emergence and development of degenerative disorders. It represents a physiological imbalance of the homeostatic system, which may be due to either an abnormal elevation of reactive oxygen species (ROS) or deficiencies in antioxidant defense systems. The liver is the most exposed organ of ROS, implies that oxidative stress often initiates liver damage; therefore antioxidant has a crucial role in preventing the onset of liver disease. Ethnomedicinal research allows obtaining many plants potential to be explored as antioxidants. Many plants used for treating liver disease were reported to have antioxidant activities (Widodo et al., 2009); therefore, it is necessary to confirm the antioxidant activities of selected medicinal plants in vitro using reliable methods such as radical scavenging activity and reducing power.

DDPH free radical scavenging is one of the accurate and the most frequently employed assay for evaluating antioxidant activity. The test was based on the bleaching of the violet solution of a stable free radical DPPH in methanol into pale yellow (Nur Alam et al., 2012). DPPH free radical in methanol has the maximum absorbance at $515 \mathrm{~nm}$. The higher the radicalscavenging activity of the extract, the lower the absorbance value at $515 \mathrm{~nm}$. The kinetic reaction between samples analyzed with DPPH free radical was monitored as a function of time to determine the operating time. Figure 1 revealed the relationship between absorbance changes ( $y$-axis) as a function of reaction time, revealing that operating time was in about 30-90 minutes depending on plant samples, as indicated that the absorbance value was stable at these operating times (Table 1). DPPH radical scavenging activity was expressed by inhibitory concentration

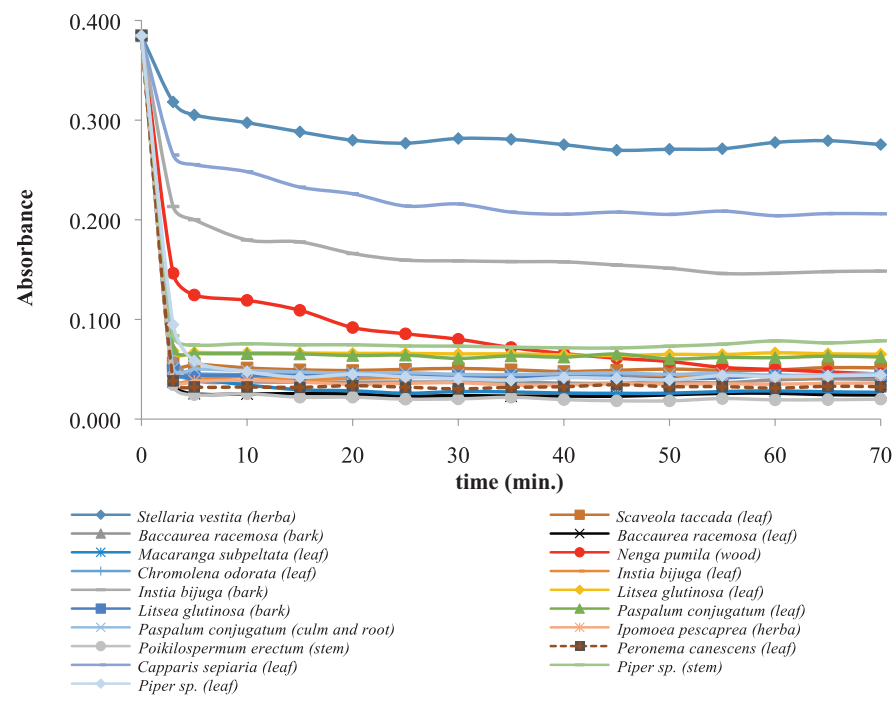

Figure 1. Time course of scavenging of DPPH free radical by methanolic extract of the plant samples. The reaction mixture contained DPPH $(70 \mathrm{mM})$ and methanolic plant extracts $(100 \mu \mathrm{g} / \mathrm{ml})$. The absorbance was measured at $515 \mathrm{~nm}$.

Table 1. $\mathrm{IC}_{50}$ value of DDPH radical scavenging of methanolic crude extract of medicinal plants used for liver diseases medication along with reference sample [vitamin C or L-(+)-ascorbic acid].

\begin{tabular}{|c|c|c|c|}
\hline Plants & Part of plant & $\begin{array}{c}\text { Operating } \\
\text { time (minute) }\end{array}$ & $\begin{array}{c}\mathrm{IC}_{50} \pm \mathrm{SD} \\
(\mu \mathrm{g} / \mathrm{ml})\end{array}$ \\
\hline Stellaria vestita & Herba & 40 & $115.128 \pm 2.931$ \\
\hline Baccaurea racemosa & Leaf & 40 & $4.298 \pm 0.306$ \\
\hline Baccaurea racemosa & Bark & 40 & $10.627 \pm 0.996$ \\
\hline Ipomoea pes-caprae & Herba & 35 & $12.932 \pm 0.489$ \\
\hline Scaveola taccada & Leaf & 60 & $23.718 \pm 1.223$ \\
\hline Nenga pumila & Stem & 90 & $26.690 \pm 1.991$ \\
\hline Chromolaena odorata & Leaf & 30 & $13.782 \pm 0.321$ \\
\hline Instia bijuga & Leaf & 35 & $8.484 \pm 0.242$ \\
\hline Instia bijuga & Bark & 35 & $71.345 \pm 2.730$ \\
\hline Litsea glutinosa & Leaf & 30 & $14.006 \pm 0.679$ \\
\hline Litsea glutinosa & Bark & 45 & $15.298 \pm 0.777$ \\
\hline Paspalum conjugatum & Leaf & 30 & $9.414 \pm 0.858$ \\
\hline Paspalum conjugatum & Culm and root & 35 & $10.482 \pm 0.465$ \\
\hline Macaranga subpeltata & Leaf & 30 & $4.139 \pm 0.150$ \\
\hline Poikilospermum erectum & Stem & 60 & $4.860 \pm 0.380$ \\
\hline Peronema canescens & Leaf & 35 & $9.389 \pm 0.679$ \\
\hline Capparis sepiaria & Leaf & 35 & $39.393 \pm 2.942$ \\
\hline Piper sp. & Leaf & 15 & $5.728 \pm 0.461$ \\
\hline Piper sp. & Stem & 60 & $17.341 \pm 0.977$ \\
\hline L-(+)-ascorbic acid & Reference sample & 30 & $2.097 \pm 0.078$ \\
\hline
\end{tabular}


$\left(\mathrm{IC}_{50}\right)$, defined as the concentration of plant sample extracts necessary to scavenge $50 \%$ of DPPH radical, calculated by an equation generated from linear regression. Among plant samples evaluated, $S$. vestita demonstrated the lowest scavenging capacity against $\mathrm{DPPH}$, as showed by its highest $\mathrm{IC}_{50}$ value. This plant is endemic to the high mountainous area of Semeru and is only used by a the IETH of Tengger ethnic in the East Jawa. In addition, the highest DPPH antiradical activity was found in the methanolic extract of $M$. subpeltata, as indicated by the lowest $\mathrm{IC}_{50}$ value. In general, the $\mathrm{IC}_{50}$ of leaves have lower values than those of barks of the studied plants (Table 1). The $\mathrm{IC}_{50}$ values of samples were higher than those of positive control; therefore, fractionation of extract was suggested to get fraction with more active antiradicals.

TEAC method, also known as ABTS [2,2'-azinobis(3-ethylbenzothiazoline-6-sulfonic acid)] radical cation decolorization assay, was based on the measurement of color loss of ABTS + having blue-green color due to the presence of an antioxidant. Plant samples containing antioxidant compounds would reduce $\mathrm{ABTS} \cdot+$ to ABTS and decolorize it at wavelength $743 \mathrm{~nm}$. Therefore, the decrease in absorbance of ABTS ++ could be used as an indication of antioxidant activity using this method. The standard calibration curve is constructed using Trolox, as a consequence, the antioxidant activity was expressed as TEAC values (in $\mathrm{mM}$ ), calculated from a standard curve of Trolox (Seeram et al., 2006). Table 2 compiled TEAC values of 14 plant samples. The higher the TEAC value, the more active the plant sample as an antioxidant. Among these, the methanolic extract of $B$. racemosa leaves revealed the highest antioxidant activities using TEAC method, i.e., $354.88 \pm 0.55$ Trolox Equivalent $(\mu \mathrm{M}$ $\mathrm{TE} / 100 \mu \mathrm{g})$. This result was in agreement with that of DPPH radical scavenging activities.

FRAP method was based on the capability of antioxidants to reduce the absorption of complex of $\mathrm{Fe}^{3+}$ ions and TPTZ due to the formation of $\mathrm{Fe}^{2+}$ ions at low $\mathrm{pH}$ at 595 nm (Benzie and Strain, 1996). FRAP value was obtained by comparing the changes of absorbance values in the sample mixture with those obtained from the increased concentrations of $\mathrm{Fe}^{3+}$. FRAP values were expressed as $\mathrm{M}$ of $\mathrm{Fe} 2+$ equivalents per g sample. Table 3 compiled FRAP values of plant samples in which the methanolic extracts of leaves of B. racemosa and Piper sp. showed the highest FRAP values, namely, 900.18 \pm 15.41 and $899.17 \pm 17.41$, respectively. The FRAP assay is simple, quick, and reproducible to evaluate antioxidant capacity, in addition, it has a direct relation with phenolics content (Parameswari and Suriyavathana, 2012).

From 19 methanolic extracts of 14 plant samples, the leaves of B. racemose, M. subpeltata, and Piper sp. showed the highest antioxidant properties, as evaluated by DPPH radical scavenging assay, FRAP, and TEAC. Therefore, these methanolic extracts of three plants extracts will be subjected to further fractionation and in vivo antioxidant assay.

\section{Classification of the plant samples using principal component analysis}

Classification of the methanolic extracts of leaf, bark, and herb of plant samples was carried out using chemometrics of PCA, one of the unsupervised pattern recognition techniques
(Che Man et al., 2011). The variables used were $\mathrm{IC}_{50}$ values of DPPH radical scavenging activity, TEAC, FRAP value, TPCs, and TFCs. Figure 2 revealed the score plot of PCA of 19 methanolic

Table 2. TEAC of methanolic crude extract of medicinal plants used for liver diseases medication.

\begin{tabular}{llc}
\hline Plants & Part of plant & TEAC \pm SD $(\boldsymbol{\mu M}$ TE/100 $\boldsymbol{\mu g})$ \\
\hline Stellaria vestita & Herba & $16.31 \pm 0.27$ \\
Baccaurea racemosa & Leaf & $354.88 \pm 0.55$ \\
Baccaurea racemosa & Bark & $135.52 \pm 0.26$ \\
Ipomoea pes-caprae & Herba & $76.14 \pm 0.14$ \\
Scaveola taccada & Leaf & $44.19 \pm 0.14$ \\
Nenga pumila & Stem & $26.16 \pm 0.34$ \\
Chromolaena odorata & Leaf & $142.79 \pm 3.15$ \\
Instia bijuga & Leaf & $148.23 \pm 0.05$ \\
Instia bijuga & Bark & $188.02 \pm 0.25$ \\
Litsea glutinosa & Leaf & $122.09 \pm 0.05$ \\
Litsea glutinosa & Bark & $165.21 \pm 0.32$ \\
Paspalum conjugatum & Leaf & $145.03 \pm 0.29$ \\
Paspalum conjugatum & Culm and root & $128.09 \pm 0.50$ \\
Macaranga subpeltata & Leaf & $297.59 \pm 0.94$ \\
Poikilospermum erectum & Stem & $310.23 \pm 5.02$ \\
Peronema canescens & Leaf & $120.28 \pm 0.12$ \\
Capparis sepiaria & Leaf & $53.71 \pm 0.03$ \\
Piper sp. & Leaf & $271.27 \pm 1.59$ \\
Piper sp. & Stem & $133.04 \pm 0.89$ \\
\hline & & \\
\hline
\end{tabular}

Table 3. FRAP of methanolic crude extract of medicinal plants used for liver diseases medication along with reference sample [L-(+)-ascorbic acid].

\begin{tabular}{|c|c|c|}
\hline Plants & Part of plant & $\begin{array}{l}\text { FRAP value } \pm \text { SD } \\
\left(\mathrm{mM} \mathrm{Fe}^{2+} / 10 \mathrm{mg}\right)\end{array}$ \\
\hline Stellaria vestita & Herba & $50.32 \pm 0.51$ \\
\hline Baccaurea racemosa & Leaf & $900.18 \pm 15.41$ \\
\hline Baccaurea racemosa & Bark & $325.79 \pm 18.85$ \\
\hline Ipomoea pes-caprae & Herb & $355.52 \pm 5.42$ \\
\hline Scaveola taccada & Leaf & $44.19 \pm 0.14$ \\
\hline Nenga pumila & Stem & $207.46 \pm 2.39$ \\
\hline Chromolaena odorata & Leaf & $394.75 \pm 7.14$ \\
\hline Instia bijuga & Leaf & $338.31 \pm 1.27$ \\
\hline Instia bijuga & Bark & $368.19 \pm 21.38$ \\
\hline Litsea glutinosa & Leaf & $282.15 \pm 11.66$ \\
\hline Litsea glutinosa & Bark & $410.48 \pm 12.01$ \\
\hline Paspalum conjugatum & Leaf & $385.13 \pm 24.74$ \\
\hline Paspalum conjugatum & Culm and root & $389.69 \pm 4.64$ \\
\hline Macaranga subpeltata & Leaf & $601.46 \pm 16.90$ \\
\hline Poikilospermum erectum & Stem & $613.75 \pm 7.75$ \\
\hline Peronema canescens & Leaf & $266.33 \pm 20.87$ \\
\hline Capparis sepiaria & Leaf & $66.82 \pm 0.54$ \\
\hline Piper sp. & Leaf & $899.17 \pm 17.41$ \\
\hline Piper sp. & Stem & $315.73 \pm 7.81$ \\
\hline L-(+)-ascorbic acid & Reference samples & $2,031.88 \pm 51.74$ \\
\hline Quercetin & Reference sample & $3,185.94 \pm 42.55$ \\
\hline
\end{tabular}


extracts of plant samples (leaf, bark, and herba), as shown in Table 1 for samples identification. Score plot of PCA was used for the classification among plant samples and it represented the sample projections expressed by the first principle component (PC1) which accounting the most variation in variables and second principle component (PC2) accounting the second largest variation of data variables. The eigenvalue indicated that $\mathrm{PC} 1$, $\mathrm{PC} 2$, and $\mathrm{PC} 3$ contributed to variable variations of $64.5 \%, 22.0 \%$, and $11.1 \%$, respectively, therefore, $97.6 \%$ of data variations could be described by three PCs. Based on the score plot, the plant samples could be classified into five groups, as clustered in Figure 2. The closer the score plot value, the closer of variables, therefore, the methanolic extract of leaves (code sample $=13$ ) was closer in terms of antioxidant activities, TPCs, and TFCs with methanolic extract of culm and root of $P$. conjugatum (code sample $=12$ ) and methanolic extract of $C$. odorata leaf (code sample =7) (Yang et al., 2015).

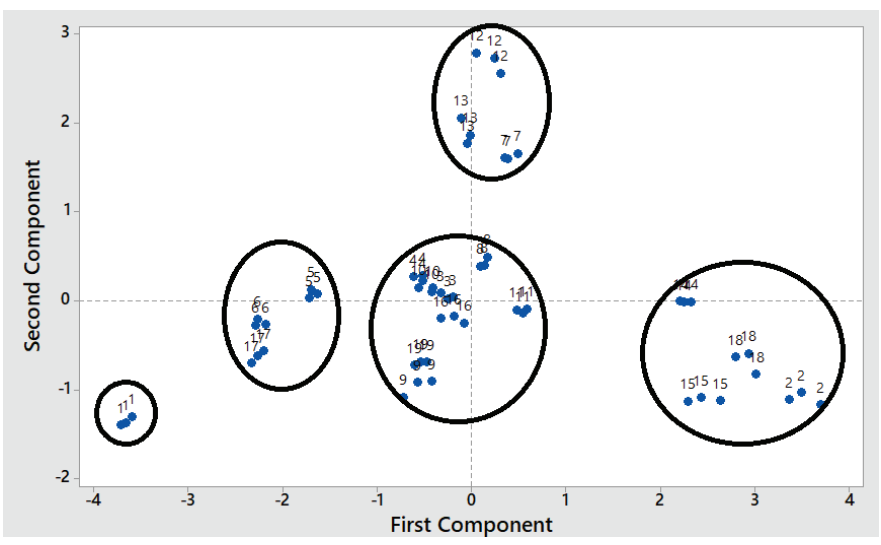

Figure 2. The PCA score plot expressed by first components (PC1) and second component (PC2) of 19 methanolic extract samples of: 1 = Stellaria vestita (herba); 2 = Baccaurea racemosa (leaf); 3 = Baccaurea racemos $a$ (bark); $4=$ Ipomoea pes-caprae (herba); 5 = Scaveola taccada (leaf); 6 = Nenga pumila (stem); 7 = Chromolaena odorata (leaf); 8 = Instia bijuga (leaf); 9 = Instia bijuga (bark); 10 = Litsea glutinosa (leaf); 11 = Litsea glutinosa $($ bark); $12=$ Paspalum conjugatum (leaf); 13 = Paspalum conjugatum (culm and root); 14 = Macaranga subpeltata (leaf); 15 = Poikilospermum erectum (stem); $16=$ Peronema canescens (leaf); 17 = Capparis sepiaria (leaf); 18 = Piper sp. (leaf); 19 = Piper sp. (stem).
In order to evaluate the correlation among variables, loading plot could be used (Fig. 3). Loading plot described how the vectors are pinned from the origin of $\mathrm{PC} 1=0$ and $\mathrm{PC} 2=0$. Loading plot was also understood as the weight of each variable to PCs. If two vectors are close, forming a small angle, the two variables are positively correlated. If among variables form an angle about $90^{\circ}$, they are not likely to be correlated, and when two variables are diverge and form a large angle (about $180^{\circ}$ ), they indicated a negative correlation. Phenolic compounds correlated with FRAP and TEAC positively and correlated negatively with the $\mathrm{IC}_{50}$ value of DPPH. The negative correlation between phenolics and $\mathrm{IC}_{50}$ indicated the positive correlation between phenolics content and antiradical scavenging activities. This indicated that phenolics compound affected significantly toward all antioxidant activities. In addition, flavonoid compounds do not contribute significantly toward antioxidant activities. Table 4 compiled the Pearson correlation as indicated with the coefficient of correlation $(r)$ values among $\mathrm{IC}_{50}$ of DPPH radical scavenging activity, TEAC, FRAP, and TFCs. The higher the $r$-value, the higher the correlation of variables. Among each variable, the correlation between TEAC and TPC exhibited the highest $r$-value (0.945). These results were similar to those reported by Katalinic et al. (2006) and Thaipong et al. (2006). Figure 4 exhibited the scatter plot for the correlation

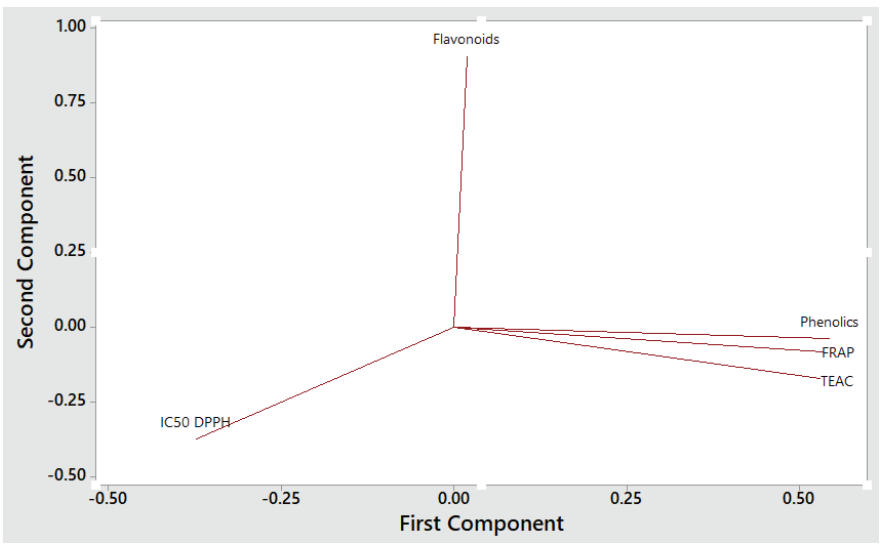

Figure 3. The loading plot of PCA using variables of $\mathrm{IC}_{50}$ values of DPPH radical scavenging activity, TEAC, FRAP value, TPCs and TFCs.

Table 4. Pearson correlation among $\mathrm{IC}_{50}$ of DPPH radical scavenging activity, TEAC, FRAP, TPCs and TFCs.

\begin{tabular}{|c|c|c|c|c|c|}
\hline \multirow{2}{*}{$\begin{array}{l}\text { Correlation among } \\
\text { variables }\end{array}$} & & \multicolumn{4}{|c|}{ Coefficient of correlation ( $r$-value) } \\
\hline & & $\mathrm{IC}_{50} \mathrm{DPPH}$ & TEAC & FRAP & TPC \\
\hline \multirow[t]{2}{*}{ TEAC } & Pearson Correlation & $-0.463^{* * *}$ & & & \\
\hline & Sig. (two-tailed) & $(0.000)$ & & & \\
\hline \multirow[t]{2}{*}{ FRAP } & Pearson Correlation & $-0.516^{* *}$ & $0.923^{* * *}$ & & \\
\hline & Sig. (two-tailed) & $(0.000)$ & $(0.000)$ & & \\
\hline \multirow[t]{2}{*}{ TPC } & Pearson Correlation & $-0.562^{* *}$ & $0.945^{* *}$ & $0.933^{* * *}$ & \\
\hline & Sig. (two-tailed) & $(0.000)$ & $(0.000)$ & $(0.000)$ & \\
\hline \multirow[t]{2}{*}{ TFC } & Pearson Correlation & -0.202 & -0.086 & -0.006 & 0.029 \\
\hline & Sig. (two-tailed) & $(0.132)$ & $(0.527)$ & $(0.965)$ & $(0.833)$ \\
\hline
\end{tabular}

**Correlation is significant at the 0.01 level (two-tailed). The numbers in parentheses are $p$-values at significant level of 0.01 . 


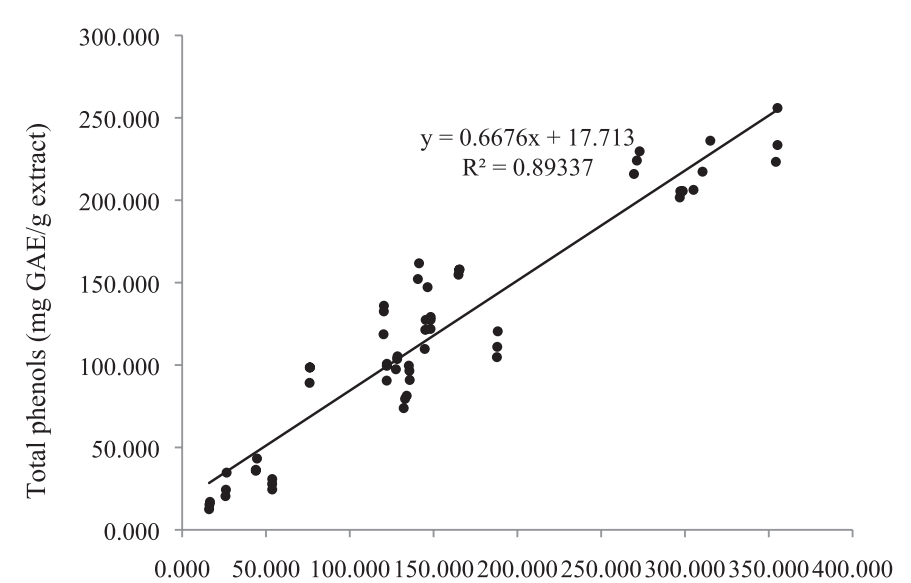

(mM Trolox Equivalent /100 mg extract)

Figure 4. The scatter plot for the correlation between TEAC ( $x$-axis) and TPC (y-axis).

between TEAC ( $x$-axis) and TPC ( $y$-axis) with the coefficient of determination $\left(R^{2}\right)$ of 0.8934 . This indicated that phenolics contents contributed to $89.34 \%$ of TEAC activities of 19 methanolic extracts of plant samples.

\section{CONCLUSION}

Among plant samples, the methanolic leaves extracts of B. racemosa, M. subpeltata, and Piper sp. showed the highest antioxidant properties as evaluated by DPPH radical scavenging activity, TEAC, and FRAP. The phenolics contents correlated with antioxidant activities. PCA successfully classified the plant samples according to antioxidant activities phenolic contents, and flavonoid contents. These three plants have promising antioxidant properties which support their utilization to prevent oxidative stress-related diseases including liver disease. A study on chemical compounds and their activity in a biological system is still needed to provide basic data on their use in traditional medicine.

\section{ACKNOWLEDGMENTS}

The authors would like to thank the Data Management Laboratory-NiHRD RI for providing a RISTOJA 2012-2017 set data and thank the Medicinal Plant and Traditional Medicine Research and Development Centre (MPTMRDC) for providing us with the research materials.

\section{CONFLICT OF INTERESTS}

Author declares that there are no conflicts of interest.

\section{FINANCIAL SUPPORT AND SPONSORSHIP}

None.

\section{REFERENCES}

Anand K, Lal UR. Hepatitis and medicinal plant: an review. J Pharmacogn Phytochem, 2016; 5(6):408-15.

Benzie IFF, Strain JJ. The ferric reducing ability of plasma (FRAP) as a measure of "antioxidant power": the FRAP assay. Anal Biochem, 1996; 239(1):70-6.

Che Man YB, Rohman A, Mansor TST. Differentiation of lard from other edible fats and oils by means of Fourier transform infrared spectroscopy and chemometrics. J Am Oil Chem Soc, 2011; 88:187-92.

Chen W, Jia Z, Pan M-H, Babu PVA. Editorial: natural products for the prevention of oxidative stress-related diseases: mechanisms and strategies. Oxid Med Cell Longev, 2016; 4628502.

Cicco N, Lanorte MT, Paraggio M, Viggiano M, Lattanzio VA. Reproducible, rapid and inexpensive Folin-Ciocalteu micro-method in determining Phenolics of plant methanol extracts. Microchem J, 2009; 91:107-10.

de Albuquerque UP. Implications of ethnobotanical studies on bioprospecting strategies of new drugs in semi-arid regions. Open Complement Med J, 2010; 2(2):21-3.

Dong JW, Cai L, Xing Y, Yu J, Ding ZT. Re-evaluation of ABTS - + assay for total antioxidant capacity of natural products. Nat Prod Commun, 2015; 10(12):2169-72.

Katalinic V, Milos M, Kulisic T, Jukic M. Screening of 70 medicinal plant extracts for antioxidant capacity and total phenols. Food Chem, 2006; 94:550-7.

Khoddami A, Wilkes MA, Roberts TH. Techniques for analysis of plant phenolic compounds. Molecules, 2013; 18:2328-75.

Li G, Yu S, Zhou Y-H, Chen Q-F. Spectrophotometric determination of flavonoids content in leaves of Fagopyrum cymosum complex. Asian J Chem, 2013; 25(13):7575-8.

Li S, Tan H-Y, Wan N, Zhang Z-J, Lao L, Wong C-W, Feng Y. The role of oxidative stress and antioxidants in liver diseases. Int J Mol Sci, $2015 ; 16: 26087-124$.

Lugrin J, Rosenblatt-Velin N, Parapanov R, Liaudet L. The role of oxidative stress during inflammatory processes. Biol Chem, 2014; 395(2):203-30

Marcellin P, Kutala BK. Liver diseases: a major, neglected global public health problem requiring urgent actions and large-scale screening. Liver Int, 2018; 38(1):2-6.

McClatchey WC, Mahady GB, Bennett BC, Shiels L, Savo V. Ethnobotany as a pharmacological research tool and recent developments in CNS-active natural products from ethnobotanical sources. Pharmacol Ther, 2009; 123(2):239-54.

Mistriyani, Riyanto S, Rohman A. Antioxidant activities of Rambutan (Nephelium lappaceum L) peel in vitro. Food Res, 2018; 2(1):119-23.

National Institute of Health Research and Development (NiHRD) of Republic of Indonesia. Laporan Nasional Riset Kesehatan Dasar 2018. Badan Penelitian dan Pengembangan Kesehatan, 2019 (In Press).

Ntie-Kang F, Lifongo LL, Mbaze LM, Ekwelle N, Owono LCO, Megnassan E, Judson PN, Sippl W, Efange SM. Cameroonian medicinal plants: a bioactivity versus ethnobotanical survey and chemotaxonomic classification. BMC Complement Altern Med, 2013; 13:147.

Nur Alam Md, Bristi NJ, Rafiquzzaman Md. Review on in vivo and in vitro methods evaluation of antioxidant activity. Saudi Pharm J $2013 ; 21: 143-52$

Pandey KB, Rizvi SI. Ferric reducing and radical scavenging activities of selected important polyphenols present in foods. Int J Food Prop, 2012; 15(3):702-8.

Parameswari G, Suriyavathana M. In-vitro antioxidant of Chromolaena odorata (L.) King \& Robinson. IRJP, 2012; 2(3):187-92.

Reinberg S. U.S. deaths from liver disease rising rapidly. 19 July 2018 (HealthDay News). Availabel via https://www.webmd.com/digestivedisorders/news/20180719/us-deaths-from-liver-disease-rising-rapidly\#1 (Accessed 25 January 2019).

Seeram NP, Henning SM, Lee R, Niu Y, Scheuller HS, Heber D. Catechin and caffeine contents of green tea dietary supplements and correlation with antioxidant activity. J Agric Food Chem, 2006; 54:1599-603.

Sharma OP, Bhat TK. DPPH antioxidant assay revisited. Food Chem, 2009; 113:1202-5.

Sochor J, Ryvolova M, Krystofova O, Salas P, Hubalek J, Adam V, Trnkova L, Havel L, Beklova M, Zehnale J, Provaznik I, Kizek R. Fully automated spectrometric protocols for determination of antioxidant activity: advantages and disadvantages. Molecules, 2010; 15(12):8618-40. 
Thaipong K, Booprakob U, Crosby K, Cisneros-Zevallos L, Byrne DH. Comparison of ABTS, DPPH, FRAP, and ORAC assays for estimating antioxidant activity from guava fruit extracts. J Food Compos Anal, 2006; 19:669-75.

Widodo H, Rohman A, Sismindari. Pemanfaatan Tumbuhan Famili Fabaceae Untuk Pengobatan Penyakit Liver Oleh Pengobat Tradisional Berbagai Etnis Di Indonesia. Media Penelitian dan Pengembangan Kesehatan, 2019; 29(1):65-88.

Yang M, Shen Q, Li L-Q, Huang Y-Q, Cheung H-Y. Phytochemical profiles, antioxidant activities of functional herb Abrus cantoniensis and Abrus mollis. Food Chem, 2015; 177:304-12.
How to cite this article:

Widodo H, Sismindari S, Asmara W, Rohman A. Antioxidant activity, total phenolic and flavonoid contents of selected medicinal plants used for liver diseases and its classification with chemometrics. J Appl Pharm Sci, 2019; 9(06):099-105. 